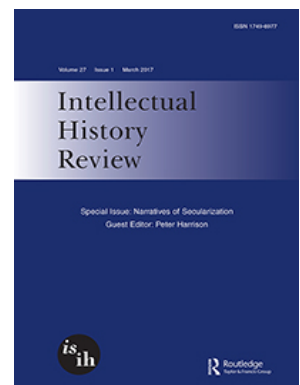

Intellectual History Review

\title{
The politics of disenchantment: Marcel Gauchet and the French struggle with secularization
}

\section{Knox Peden}

To cite this article: Knox Peden (2017) The politics of disenchantment: Marcel Gauchet and the French struggle with secularization, Intellectual History Review, 27:1, 135-150, DOI: $\underline{10.1080 / 17496977.2016 .1255464}$

To link to this article: https://doi.org/10.1080/17496977.2016.1255464

曲 Published online: 16 Jan 2017.

Submit your article to this journal

џ Article views: 377

Q View related articles $₫$

View Crossmark data ¿

4 Citing articles: 2 View citing articles $\square$ 


\title{
The politics of disenchantment: Marcel Gauchet and the French struggle with secularization
}

\author{
Knox Peden \\ School of Philosophy, RSSS, Australian National University, Canberra, ACT, Australia \\ ABSTRACT \\ This article looks at Marcel Gauchet's major metahistorical \\ statement, The Disenchantment of the World: A Political History of \\ Religion (1985), and uses it to advance a series of claims about the \\ place of secularization in debates within and about French \\ politics, especially in relation to modern French history. The \\ argument is put forward that Gauchet's work is best understood \\ as offering an alternative philosophy of history to Marxism that \\ could serve to support a broadly republican realignment of \\ French politics in the 1980s. Revisionist historiography concerning \\ the French Revolution likewise played a role in this development, \\ and served as a prerequisite of sorts to Gauchet's broader \\ historical project. The article also considers Gauchet's work in light \\ of postmodern skepticism of the utility of historical metanarratives.
}

\section{KEYWORDS}

Marcel Gauchet;

secularization; philosophy of

history; postmodernism;

republicanism;

historiography; French

revolution

An old saw has it that all politics is local. But narratives of secularization tend to be global. The aim of this essay is to account for the political character of a powerful account of world-historical secularization that emerged in France in the 1980s and that remains important to debates in French intellectual life today. Much recent literature on the place of religion in French politics has concerned itself with questions of laïcité and France's nominal status as a secular republic. ${ }^{1}$ But behind the debates about republican secularity (whatever that might ultimately mean) is an ongoing contestation about the nature of politics in French history after the Revolution of 1789. For decades, the modernity ascribed to French politics was one consistent with the doctrines of Marxism and its historical vision, in which the political structures inaugurated with the overthrow of the monarchy were to serve as mere fulcrums for a transformation of the social conditions of capitalism still to come. Such is by no means taken for granted today, whatever the uptick of sympathy for Marxist and broadly Marxisant analyses in the wake of the global financial crisis of 2008 .

The specific subject of this article is the work of Marcel Gauchet, who in recent years has effectively rewritten the history of modern French politics so as to displace this Marxist vision. But the main focus of what follows is his major metahistorical book The Disenchantment of the World (1985). The title of Gauchet's work plays on Max Weber's classic thesis. Yet it also signals the place of normativity in how we think about the history of religion, suggesting that secularization is a process we might have some

CONTACT Knox Peden knox.peden@anu.edu.au

(c) 2016 International Society for Intellectual History 
reason to regret or at least be troubled over. The earnestness of Gauchet's effort is significant, especially when considered in light of claims about world-historical narratives that were advanced in France in the years before he published his major statement. For this reason, before turning to this work directly, it might be worth pursuing a preliminary effort to situate it historically.

\section{Post-postmodernism?}

In 1979, a commission on universities established by the Quebecois government approached the French philosopher Jean-François Lyotard with the request to prepare a 'report on knowledge in the most highly developed societies.' No exercise in bookkeeping, the resulting document appeared that same year with the avant-garde publishing house Editions de Minuit and was translated into English several years later in the University of Minnesota Press's pioneering 'Theory and History of Literature' series. Eponymous in its relation to a moment of theoretical reflection in the humanities, The Postmodern Condition is perhaps best remembered for Lyotard's most terse and basic claim: 'Simplifying to the extreme, I define postmodern as incredulity toward metanarratives. ${ }^{2}$ Note that it is the adjective postmodern, rather than the nouns postmodernity or postmodernism, that Lyotard defines, and that its referential content describes a disposition or stance. One is postmodern in one's convictions when one is incredulous toward metanarratives. The ubiquity of this incredulity in France in 1979, not to mention the Anglophone world, is difficult to gainsay. With the dark turn of so many political projects that appealed to a historical narrative for justification communism, to be sure, but alongside it imperialism and de-colonization, each of which could invoke Enlightenment rationalism for its cause - Lyotard's text described and indeed advocated a condition in which intellectual life remained skeptical toward discourses of legitimation and sought instead to affirm the incommensurability of language games as the ethic appropriate to the age. ${ }^{3}$ In Lyotard's assessment, which echoed Michel Foucault and other contemporaries, exploitative relations of hierarchical subjugation had given way to relational practices of optimization gathered around a single criterion: efficiency. 'The application of this criterion to all of our games necessarily entails a certain level of terror, whether soft or hard: be operational (that is, commensurable) or disappear. ${ }^{4}$

The resonance of Lyotard's claim more than 30 years on need not be emphasized. More striking, however, at least to those used to thinking of postmodernity as yet another stage in a poorly wrought metahistorical schema - a dystopian surrogate for the utopia that modernity promised but never delivered - is Lyotard's insistence that 'the postmodern condition is as much a stranger to disenchantment as it is to the blind positivity of delegitimation. ${ }^{5}$ In Lyotard's view, the latter is not an alternative to the former but an instance of it. Positivist efforts at delegitimation, whether they take the form of historical revisionism or empirical corrective, are captive to a logic of disenchantment in that they presuppose that those who err are, at root, enchanted and can be corrected by a delegitimizing practice that is little more than the ground-clearing for a new discourse of legitimation. In other words, disenchantment ought not to be the goal of a critical practice in a postmodern age since the story of disenchantment is arguably the historical metanarrative par excellence. No stranger to irony, Lyotard was deliberate when he named the substance of the postmodern condition 'incredulity.' We do not believe in the story of the loss of our belief anymore. 
Irony has long been integral to the modern discourse on disenchantment. As Max Weber famously remarked in 1918: 'The fate of our times is characterized by rationalization and intellectualization and, above all, by the "disenchantment of the world". ${ }^{6}$ Alluding to Schiller, the source of the phrase as well as its ironic inflection, Weber presented disenchantment as a process endowed with its own enchantments. 'Today the routines of everyday life challenge religion,' he says. 'Many old gods ascend from their graves; they are disenchanted and hence take the form of impersonal forces. ${ }^{7}$ Weber's greatest fear was that the moderns would become too enchanted by the disenchantment of the world, too blind in their devotion to the 'impersonal forces' that have replaced the gods of yore, and the result would be the 'evasion of the plain duty of intellectual integrity, which sets in if one lacks the courage to clarify one's own ultimate standpoint.. ${ }^{8}$ The goal of this ethic, the one supporting academic knowledge as a vocation, was not directed toward truth or the constitution of new objects of knowledge, but instead toward a lacerating honesty grounded in self-reflection and candor. In this regard, Lyotard is Weber's inheritor, and this not despite, but because of, the fact that Lyotard himself came to regard his report as 'a bit of parody.' The play of discourses and the ethics of blindness cultivated in his work are not the machinations of an evasive rhetoric and an insidious intellectual program. They are the reflections of a French radical intellectual attempting to come to terms with the thoroughly ironic - and potentially intractable - position of no longer believing in the possibility of an intellectual practice capable of redeeming us from false beliefs.

Amid this saturation of irony, it is of course no doubt ironic that six years after Lyotard's book defined the condition of the age, Marcel Gauchet published the volume that remains the centerpiece of his thought, The Disenchantment of the World, with the pointed subtitle A Political History of Religion. Brazenly speculative, the book was unapologetic in its design to offer, precisely, a new metanarrative, one that sought to combine 'the pure theory of the conditions of possibility for being-a-self and collective-being' alongside 'a more extensive investigation of some particularly representative instances of the manifestation and operation of the transcendental in the empirical realm. ${ }^{10}$ For Gauchet, an avowed atheist and arguably France's leading center-left public intellectual, the transcendental was not to be confused with an other-worldly sphere or site of transcendence. Indeed, the signal innovation of Judaism was not so much the introduction of monotheism as the constitution of transcendence as such, the invention of the very notion of a divine space as one other than the world. The relation between these spaces, the quandary of the 'presence of the transcendent' once it was constituted and deemed 'absent,' proved to be the dialectical motor of religious history ever since, culminating in the protracted 'exit from religion' that Christianity has bequeathed the secular age. ${ }^{11}$ By contrast, along Foucauldian lines, or indeed post-Kantian lines more generally, Gauchet regarded the transcendental as the 'conditions of possibility' named on the first prong of his approach, the a priori structures that obtain and make experience of the world possible. Like many, Gauchet presented these transcendental conditions as invariant, and yet historical. Like many, his account of how they can be at once invariant and historical leaves something to be desired. ${ }^{12}$

The quandaries generated by Gauchet's 'transcendental anthroposociology' are akin to those found in any robust speculative effort. ${ }^{13}$ And, as usual, whether one regards these quandaries as signs of theoretical fecundity or cognitive impoverishment is to an extent 
a matter of the viewer's stance, if not taste. In Gauchet's case, however, what makes the narrative of secularization in his work worthy of interest is the way in which it is explicitly and indeed avowedly conditioned not simply by Gauchet's own personal political itinerary, but by key shifts in French intellectual and political culture out of the 1970s and into the 1980s. In other words, no real hermeneutic of suspicion is required to discern the activist program of Gauchet's account of secularization because its tendential elements are actively thematized in the account itself. This is why it is significant that the historical condition of Gauchet's account is effectively post-postmodern. Though Lyotard was a generation older than Gauchet, they shared similar intellectual genealogies in their gauchiste pasts and their disillusionment with Marxism. ${ }^{14}$ Where Lyotard counseled a skeptical stance toward the metanarratives of which Marxism was one instance, Gauchet considered that if narrative itself was an inescapable aspect of historical and political thought - and the fact that Lyotard's account of the incredulity toward metanarratives took the form of a narrative suggested that it was - then the most urgent task for a politically engaged French intellectual was not to indulge this incredulity, but to produce a more salutary metanarrative. With the narratives of modernity in bankruptcy, Gauchet seized the opportunity to develop a new narrative that would incorporate many of the insights of modern philosophy and the human sciences, but which would serve finally to buttress a fundamentally liberal, albeit distinctively French, conception of democratic republicanism rather than erode it.

In the context of French intellectual life, there was no doubt about the most significant barrier to such a project. In a 2003 reflection on his itinerary at the end of the 1970s, Gauchet remarked:

the key to the political situation in which we found ourselves [...] resided in a theory of history capable of giving the lie to Marxism, not only by attempting to critique it on specific points $[\ldots]$ but by proposing an alternative vision. ${ }^{15}$

This 'giving the lie to Marxism' is in turn the key to the intelligibility of Gauchet's narrative of secularization in terms of its theoretical content, its contextual emergence in French political culture, and its nascent reception in the Anglophone world. This schema also yields the blueprint for the remainder of this article, which will focus first on the contents of Gauchet's work before turning to consider the context of its emergence and, briefly, its Anglophone reception in recent years. In closing, I will remark briefly on the implications of Gauchet's work and its reception in order to suggest that, to the extent that they concern what aspects of social life are amenable to transformation, debates over secularization are, in the end, primarily political in character.

\section{The exit from religion}

The Disenchantment of the World is a deceptively difficult book. Despite its relative brevity, the combination of theoretical abstraction with a descriptive narrative often makes it hard to follow the thread of Gauchet's argument. It is nevertheless reliably full of sparkling apercus, for example: 'Religion, in its original pure state, is the desire to merge with nature;' 'Christianity's liberating originality lay in its indirect transmission'; or, 'Only when the gods have disappeared does it become obvious that men are not gods. ${ }^{16}$ Alas, the speculative register also risks a measure of turgidity, especially in 
translation, for example: 'The modest bifurcation of political Augustinism, in accordance with the ontology of Christ's two natures, was the starting point for reinstituting the human world in terms of equality' or, 'This capacity to create political perpetuity along with social novelty is a key to western historicity. ${ }^{17}$ To be sure, such phrases are intelligible in the terms of Gauchet's account, but at times it does seem that Gauchet is perhaps too eager to demonstrate the salutary function of opacity that is one of his core arguments.

Indeed, this positive brief for the world's opacity, and in particular its increase rather than its diminishment, is one of the more provocative elements of Gauchet's overarching thesis. It is a commonplace of popular science that the more we know of the universe, the more mysterious it becomes. Gauchet sees a similar process at work in the 'political history of religion' and its various concepts of authority. In Gauchet's view, the mystique of authority is not an essential aspect of religion as such. Rather, it is essential to the particular monotheism created by Judaism and further developed by Christianity. The cunning of religious history for Gauchet has resulted in the rendering immanent of this contingently original transcendence. In the process, the 'other' loses its mystique, but none of its opacity. The point is that, in modern democracy, we have arrived at a state not simply where we regard the locus of sovereignty as invisible and unrepresentable, but that this inscrutability has become as much a source of security as of existential anguish.

In the years since he wrote The Disenchantment of the World, Gauchet has become less sanguine about democracy's prospects, even as he has developed a speculative history of democracy that deepens the analysis of the earlier book. ${ }^{18}$ But the matrix of both efforts remains the same. The schema of Disenchantment can be gleaned from the inversion of a familiar presumption about religion's historical forms at its core. In Gauchet's view, Western Christianity is not religion's optimal form, but its most compromised and destitute. Indeed, the purest religions the world has seen are to be found in the various paganisms of primitive man, those described by Durkheim, Lévi-Strauss, and the anthropologist with the most decisive impact on Gauchet's thought, Pierre Clastres. ${ }^{19}$ During this time, the 'gods' are fully part of the world, coextensive with it in every way. In a word, there is no conception of transcendence. By establishing the mechanism of law and thereby giving rise to the very concept of law, however inchoate - a set of relational norms to which one relates in a mode of subjection - the advent of Jewish monotheism also witnesses the creation of a domain of the 'invisible.' This domain has the peculiar status of being at once constitutive of the world, but opaque to it as well. Law's power comes from this paradoxical quality, and the sense of law here applies in the dual sense of laws of nature and the moral laws of a community; in both cases, the 'laws' describe what works, but we know nothing of their source. They account for everything except their own advent.

To be sure, Gauchet regards the advent of this concept of invisible authority as contingent, 'borne by the dynamics of empire' that buffered 'a tiny sliver of land situated between major civilizations. ${ }^{20}$ But once the development takes hold, the 'dynamics of transcendence' take over. The past two millennia are the history of these dynamics and the migration of 'invisible' authority from the divine sphere to the secular sphere of the State via the intermediaries of hereditary monarchy, who served as transitional and literally personified avatars of an otherwise 'invisible' authority. With the destruction of personified sovereignty in the regicide that defines the modern era - Gauchet is nothing if not French - the locus of authority finally and truly becomes invisible, wholly without 
representation in the world. The nineteenth-century cult of the nation is a hangover from the religious era, as is the mode of charismatic authority that was nationalism's twentiethcentury inheritance. Despite these vestiges in the familiar presentation of totalitarian ideology as 'secular religions,' the real gift of this collapse of religious transcendence is the rendering of the state and its institutions finally impersonal. This is why bureaucracy is a valorized term in Gauchet's account (again, nothing if not French). The opacity of the bureaucratic state is an opacity that hides nothing and is transparent about this fact. ${ }^{21}$ From the opacity of immanentized transcendence to the impersonality of bureaucracy in the democratic state, Gauchet's abstractions find their concrete correlates.

This affirmative stance toward the state is essential to Gauchet's political thought and its rejection of all forms of anarchism and revolutionary or utopian politics. As Samuel Moyn has summarized Gauchet's view, 'to be against the state, $[\ldots]$ you have to be for one version of it. ${ }^{22}$ This political stance resonates too with Gauchet's assessment of morality as similarly intractable in a secular age. 'The death of God does not mean that man becomes God by reappropriating the conscious absolute self-disposition once attributed to god; on the contrary, it means that man is categorically obliged to renounce the dream of his own divinity. ${ }^{23}$ With these remarks near the conclusion of The Disenchantment of the World, Gauchet offers his own take on Nietzsche's most famous pronunciamento and also makes clear what distinguishes his project from similar accounts of secularization that locate the dynamics responsible for the 'exit from religion' inside Christianity itself. For Gauchet, the death of God is not a cause for regret, since, in a word, it makes a democratically organized society possible, one in which bureaucratic opacity is a condition of its possibility rather than an affliction to be overcome. ${ }^{24}$ Citing Lacan, Gauchet's volume ends with an encomium to ambivalence as democracy's greatest value because it is the political form most proximate to 'the daily throbbing pain that no sacral opiate can blot out: the merciless contradictory desire inherent in the very reality of being a subject. ${ }^{25}$ If the history of Christianity as an equally symbolic and social form is what made such a reckoning possible, it is because its 'modalities' were particularly well-suited to mediate and ultimately accentuate the relation between two equally fractured relations, that of the self to itself, and that of collective-being to itself as a collective via the medium of these already fractured selves. ${ }^{26}$ In other words, Christianity is the historically contingent modality that makes evident the non-contingent basis of subjectivity as such - as fractured and incomplete, riven by time and desire. What has changed, in Gauchet's view, in the secularization wrought by the negative theologies of modern Christianity and the political efforts to establish authority in the inscrutable abstraction of the State, is that it is no longer the divine space of the other that is unrepresentable, but the temporal future that is its secular correlate: the unknown that awaits and for which we are ultimately responsible. But Gauchet's concept of futurity is one that anathematizes the Jacobin and Communist inheritance. Modern, ostensibly secular efforts to know the future are correlative to earlier efforts to know God's will. Fanaticism is the tie that binds the religious to the secular instance. ${ }^{27}$

To return to the main tension of Gauchet's argument noted at the outset, his history of religion seems to come to down to a history of the contingent discoveries of a necessary structure. In this, Gauchet's attitude to the 'political history of religion' is paradoxical in a familiar way. He comes to bury religion, but also to praise it for allowing a more sober reckoning with humanity's true, far from divine, condition. At this point, it seems 
germane to recall Marx and Engels' similarly ambivalent attitude to the 'bourgeois epoch,' and the capitalism that was its content:

All fixed, fast-frozen relations, with their train of ancient and venerable prejudices and opinions, are swept away, all new-formed ones become antiquated before they can ossify. All that is solid melts into air, all that is holy is profaned, and man is at last compelled to face with sober senses, his real conditions of life, and his relations with his kind. ${ }^{28}$

In terms of its structure as an 'alternative' to the Marxist 'theory of history,' Gauchet finds the surrogate for capitalism in Christianity. Or, to put it more precisely, in the history of Christianity Gauchet finds a set of corrosive and emancipatory 'modalities' similar to those Marx found in the nascent history of capitalism. But capitalism and Christianity are both species of the concepts that form the true site of analogy between the two efforts: religion and mode of production. Like the Marxist 'mode of production,' Gauchet's religion is a historical invariant capable of accommodating a variety of shifting and overlapping forms. In its formal vacuity, this invariant is not itself socially determinant, but its contents are deemed to be so, depending on their contingent arrangement in a given epoch. In the end, Gauchet recuses the 'materialist conception of history' in order to accentuate the primacy of the symbolic forms and practices of human community that are most readily legible in religion's history.

This inversion of Marx is itself a feat of striking irony; does not this just return us to Hegel? Even some of Gauchet's most charitable critics have remarked on this unavowed Hegelianism of his project, which 'places extraordinary weight on historical transformation operating on the symbolic level. ${ }^{29}$ Indeed, in Gauchet's history there is hardly any space for material relations, much less the figure of the economy. What is primary are the modes and habits of thought that gain traction though various contingent social arrangements, habits which obtain, in the end, because they tap into and exploit an evidently fundamental structure of human subjectivity. Gauchet's work is often presented as a kind of philosophical anthropology, but the psychoanalytic component of his work is arguably more suggestive in this regard. The modern age has seen an overweening emphasis on will and humanity's 'stubborn tendency to increase its power and objectify its freedom.' 'But hidden in the depths of time,' Gauchet continues, 'is another humanity whose secret has been lost, and needs to be rediscovered, one that found a way to be at one with itself in its accepted dependency and its passive relation to the world. ${ }^{30}$

This recuperative stance toward 'passivity' against humanity's stubborn tendencies is a rebuke to a voluntarist conception of political modernity. In Gauchet's view, it is paradoxical that we find the institutions that we have created obscure and yet regard the world and nature as transparent to our will:

This fundamental paradox contains the key to our entire history, for the essence of religion is both to gain self-possession by consenting to dispossession, by turning away from the goal of dominating nature and to legislate on our own behalf, namely that of securing an identity defined and controlled at every step. ${ }^{31}$

If Gauchet is ambivalent about the challenges of 'securing an identity' he is less so about the process of dispossession as the paradoxical key to self-possession, be it via organized religion or the modern State, the latter of which merely rearranges a set of relationships found in the earlier 'articulation of the human situation. ${ }^{32}$ The goal is not to overcome 
alienation, but to accept it as constitutive. Here we are at the antipodes of Marx's 11th thesis on Feuerbach, which counsels philosophers to change the world where they have heretofore only interpreted it. ${ }^{33}$ With its twin rejection of 'historical materialism' and the voluntarist element in political history, Gauchet's project is a rejection of the Marxist inheritance and its French inflection. A symptomatic point about his narrative highlights this point. In a fundamental way, the French Revolution is the turning point of the modern era in Gauchet's account. The regicide of Louis XVI is what makes possible, finally, the immanentization of political authority in all its opacity. But nowhere is this event narrated in his book. And even when he finally describes this event later on, in a central chapter of La révolution moderne, the story is not that of directed political action and its consequences, but that of a system of interlocking dynamics to which historical actors passively submit as vectors toward new symbolic arrangements of political life. ${ }^{34}$

\section{3. 'The revolution is over'}

The negative model of Marxism is legible in Gauchet's work on its own terms, but the reasons for this negative inscription become clearer if we consider the heated intellectual and political context whence it emerged. A spirited historiography has materialized over the past decade that has greatly clarified the extent to which a cohort of French intellectuals, beginning in the late 1970s, deliberately targeted the Marxist framework in historical, political, and philosophical thought in order to generate an intellectual ethos better suited to a nominally post-ideological age. ${ }^{35}$ Although Gauchet has come to be one of its leading representatives, its most emblematic founding figures were the philosopher Claude Lefort and the historian François Furet. Both of these thinkers were formative for Gauchet's own project. Lefort is widely recognized for giving the political theory of totalitarianism an existential cast. Locating the threat of totalitarianism in the democratic enterprise itself, Lefort insisted that political vigilance meant taking pains to preserve the 'empty space' of democratic legitimacy. ${ }^{36}$ Furet, for his part, was instrumental in marshaling an epochal shift in the historiography of the French Revolution. In his central statement, Penser la Révolution française, published in 1978, he declared 'the Revolution is over. ${ }^{37}$ What he sought was a reconfiguration of French political culture away from an interminable debate over the Revolution's legitimacy, wherein French thinkers would be stuck execrating or celebrating the event, 'both of which are ways of commemorating ${ }^{38}$ rather than understanding it historically. Of course, in seeking to terminate the debate, he also sought to have the last word on the subject.

Though polemical, Furet's effort was no ideological hatchet-job. Indeed, by moving away from the Marxist emphasis on class conflict grounded in putatively social bases a historiography which had in fact begun to encounter a number of empirical stumbling blocks $^{39}$ - toward a focus on symbolic forms and ideological dynamics, he ushered in a historiography that would be foundational for much of the new cultural history in the Anglophone context. ${ }^{40}$ Turning Marx against Marxism, Furet cited from The Holy Family to agree with Marx's gloss on Thermidor - which saw the end of the Terror as 'the reassertion of real society over the illusion of politics." ${ }^{41}$ Against 'Leninist jargon-mongers,' Furet insisted that 'its permanent tendency to skid out of control and to contradict its own social nature marks the revolutionary process as an autonomous 
political and ideological movement that must be interpreted and analysed as such. ${ }^{42}$ As with Gauchet's later account of the political history of religion, Furet treated the dynamics of this movement as at once isolated from other practical arrangements and determinative of them. These dynamics are 'autonomous,' and yet somehow still contradictory in their relation to a disavowed social base.

At the center of Furet's substantive account of the French Revolution was a recuperation of the Tocquevillian idea that what the Revolution accomplished in the end was not an overturning of the Old Regime but a consolidation of its bureaucratic tendencies toward administrative centralization. ${ }^{43}$ In recovering this historiography, Furet was also recovering a moment of nineteenth-century political thought grounded in the Restoration and the later experience of the July Monarchy. If Furet's hero was Tocqueville, Gauchet's was Benjamin Constant. ${ }^{44}$ Pierre Rosanvallon, another of this cohort and currently Professor of Modern and Contemporary History of Politics at the Collège de France, wrote on François Guizot. ${ }^{45}$ And Pierre Manent, who has devoted much energy to developing a history of liberalism that accounts for the distinctive features of French republicanism, also produced an important book on Tocqueville. ${ }^{46}$ What all these recuperated figures have in common is that they were political thinkers who were also statesmen, figures who recused any moral space outside the political sphere, from which they might shout, with Voltaire, Ecrasez l'infame!, in order to reconcile themselves with the apparatuses of government. ${ }^{47}$ This reconciliation with government was also a mode of reconciliation with the historical fact of the revolutionary experience, its gains as well as its horrors. ${ }^{48}$ This is what sets thinkers like Guizot and Constant apart from Joseph de Maistre within the spectrum of reaction. ${ }^{49}$ It also accounts for their appeal to a group of center-left intellectuals more than a century later eager to break with Marxian modes of thought but reluctant to jettison the gains of anticolonial and republican struggle altogether.

And yet, the reconciliation with a vaguely liberal restorationist take on the Revolution in terms of historiography and political thought involved another kind of reconciliation as well. In 1980 Gauchet launched the journal Le Débat with the historian Pierre Nora. Nora's inaugural editorial -'Que peuvent les intellectuels?' - made clear that intellectual work could no longer take a stance outside of government and industry, but had to reconcile itself to the reality of the modern democratic state in its fraught and conflicted nature. Around the same time, Furet founded the Saint-Simon Foundation, a think tank devoted to developing a more comprehensive form of liberalism that could reconcile market forms with French conceptions of republicanism. Its commitment to economic liberalism was of a piece with the general anti-totalitarianism of the age, but it also signaled the end of any kind of political critique of capitalism as a historical abstraction. A meliorism of damage control was deemed the best hope to temper the corrosive effects of the neoliberal developments pursued under the Mitterand government following upon a period of polarized intransigence of Gaullism on the right and Communism on the left.

What does this have to do with The Disenchantment of the World? Apart from the fact that Gauchet himself was central - institutionally and intellectually - to this general shift in French intellectual life, this anti-Marxist reconciliation to the market as a kind of equalizer makes its way into the speculative arguments of Gauchet's major theoretical statement. In the closing pages of the book, which has had nary a discussion of economic life, much less economic thought, within it, Gauchet introduces the following provocation: 
[C] onflict over the organization of the political society is the formal equivalent to the market as the structuring principle of civil society, and is also the necessary counterpart, within the political system, of the impersonality of power. [...] Such is the cohesive principle of the collective as subjective form. Hence the political competition organized by the representation of divergent class interests, the opposed versions of the collective's future constitution, and the disagreement on everything other than the principles of confrontation, instaurates a social self transcending the consciousness of the actors through whom it is established and operates. $^{50}$

With this passage, Gauchet not only advocates a mode of agonism similar to other twentieth-century Kantianisms, from Arendt's to Habermas's; he actively ties that agonism to the economic sphere in such a way that it is no longer simply a matter of inverting the Marxian frame - in which the economic determines the political - but of establishing that the spheres of economic and social life have no substance of their own, but are instead further sites of the political. As with Furet's focus on ideological dynamics 'skidding out of control,' politics has become divorced from society in this vision. But this politics is itself a distinctly metaphysical kind of politics, one that saturates the very forms of life described by anthropology, finally becoming indifferent to the extra-political goals of political activity. In this vision, politics is no longer a conflict over substantive matters, because politics is the only substance there is.

As Warren Breckman has recently remarked, 'The history of the disenchantment of the world [...] served Gauchet as a vehicle for expressing a generation's disenchantment with its former political commitments. ${ }^{51}$ And indeed the ironies of disenchantment identified at the outset return in the notion that Gauchet's work is itself a kind of local effort at ideological disenchantment. As with much critical writing on Marxism, the rhetoric of these efforts often indulges figures of maturation and the outgrowing of youthful naiveté, a narrative whose form mimics that of the secularization narrative as such in its variously Hegelian iterations.

This same mode of presentation has shaped much of Gauchet's Anglophone reception. His work was first translated in Mark Lilla and Thomas Pavel's 'New French Thought' series for Princeton University Press in the 1990s. This series was explicit in its partisan aim to introduce 'the younger generation of philosophers, historians, and social commentators who represent the new liberal, humanistic bent of French intellectual life. ${ }^{.52}$ In case there was any doubt that the target was not simply the Marxisant tendency of French thought in its reception, but the obscurantism of poststructuralism as well, the same note promised 'clear and accessible translations' aimed at a 'cultivated public." 53

Fortunately, this patronizing element has been tempered, if not wholly eliminated, in the reception work undertaken by Samuel Moyn, Warren Breckman, and Michael Behrendt, where there nevertheless remains a level of sympathy with Gauchet's generational disdain for more exuberant conceptions of political change. ${ }^{54}$ In Moyn's case in particular, Gauchet's powerful critique of human rights as a kind of vacuous ideological veneer for an interregnal moment after Marxism's decline and prior to the liberal-republican synthesis that he would promote with others in the 1980s, has proven a remarkable stimulant. ${ }^{55}$ To be sure, this reception has hardly been uncritical, but the appeal of Gauchet's work does seem to lie in its attempt not to depart from social theory, but instead to produce a comprehensive theory that can rival the Marxist paradigm and yet avoid its pitfalls. 
Not surprisingly, one of the most compelling critiques of Gauchet's work thus far has come from a Marxist perspective in a series of recent articles by Jacob Collins in the New Left Review. In a comprehensive assessment of the 'anthropological turn' in French thought, Collins shows how Gauchet and others have sought to reactivate a natively French mode of anthropological inquiry with roots in the nineteenth century. Reclaiming Marx and Engels' Holy Family for his own purposes, Collins concludes:

In activating France's dormant anthropological tradition, these thinkers [Gauchet et al.] have concealed and obfuscated the materialist bases for social and political relations. Their attention to idealist constructions [...] can only obscure the character of the relations of production, and foster an idealist conception of political community. What emerges is a common propensity for 'the art of changing real objective chains that exist outside me' into 'mere ideal, mere subjective chains existing in me' - 'and thus to change all exterior palpable struggles into pure struggles of thought'.

Collins's critique is cogent as far as it goes. But where it goes is precisely back into a canonical Marxism. The emphasis, in Gauchet's work, on religion and the dialectic between heteronomy and autonomy that it brokers has now swung back to the emphasis on the 'relations of production.' Put differently, if Collins targets Gauchet for concealing and obfuscating 'the materialist bases for social and political relations,' it is because he thinks another theoretical framework might be able to disclose and clarify them. As a theoretical framework, Marxism certainly has a plausible claim to be able to do so. But the symmetry is almost too neat. It is hard to remain under the illusion that this dispute between the primacy of the political or the social, the religious or the material, is in itself dependent upon anything but the moral force of the worldviews in question. In other words, the question of who is enchanted and who is disenchanted - who is and who is not beholden to an ideology - is not one that will ever be decided objectively or empirically. Lyotard cultivated his conviction that that age of metanarratives as vectors of ideology had finally been eclipsed. The debates over secularization cultivated by Gauchet's work suggest the opposite, namely, that ideology is not a barrier to political engagement, but a condition of it.

\section{Conclusion}

Gauchet's narrative is schematic, but it remains an open question whether this attribute is an indelible feature of any account of secularization as a world-historical process. As with most historical matters, the altitude at which the lens is situated will in many respects determine the strata at which the motors of historical change will be located. Gauchet's project rivals Marxism to the extent that it grounds its account in a totalizing philosophical anthropology in a more or less explicit way. But then again it is hard to conceive of any account of human action that does not harbor certain anthropological presuppositions about the place of intention in explaining such action, which is to say, ideas about what distinguishes human actions from other kinds of natural events that make up the historical record. The watchword of Marxism on this score (if not that of Marx himself, apart from early collaborations with Engels) is of course ideology. The predominant account suggests ideology explains action to the extent that it explains actions that are somehow distorted, or not fully informed, shaped by determinants of which actors remain unaware. But efforts on the part of so-called postmodernists and others to have done with ideology - not the 
thing itself, but the very concept, as itself somehow distorting - have served instead to accentuate the ways in which any putatively natural or objective view of the past will invariably be colored by a set of political commitments and judgments. It would seem that ideology does not cease to be ideology just because we become aware of it as ideology.

Objectivity is not so much compromised in this vision as it is augmented, complemented by a certain explicitness about what motivates historical investigations and the narratives that result. At the outset, I suggested that Lyotard's frivolity was consistent with Weber's ethic to the extent that it was explicit. Gauchet's work, like Furet's and others of his ilk, has a similar ethical candor to the extent that it is explicit about its ideological aspirations. But the main point remains that the politics of secularization is not going to be determined or decided by some appeal to a fundamental historical reality or arriving at some nominally correct narrative of secularization which everyone will ultimately recognize as true. Politics does not find its answers in the empirical record. But then again the aim of politics has never been so much about finding answers as it has been about shaping consequences. If every narrative of secularization is political in this way, then the criteria for judging them perhaps ought to be political as well. And if both Marxism and Gauchet's alternative leave something to be desired on this score, this is a reflection perhaps of their political limitations rather than their theoretical ones.

\section{Notes}

1. See inter alia Scott, The Politics of the Veil.

2. Lyotard, The Postmodern Condition, xxiv.

3. The positive aspect of this ethic is more fully developed in Lyotard, The Differend.

4. Lyotard, The Postmodern Condition, xxiv.

5. Ibid.

6. Weber, "Science as a Vocation." The citation is on page 155.

7. Ibid., 149 .

8. Ibid., 155 .

9. Cited in Anderson, The Origins of Postmodernity, $26 \mathrm{n} 25$.

10. Gauchet, The Disenchantment of the World, 16.

11. Ibid., 101-6, 109, 114-15.

12. Cf. Cantin, "Aux sources du Désenchantment du monde." See Cantin's comments on 507: "There is something of the transcendental in history", Gauchet declares in the Introduction of his book (1985; xiv [English translation, p. 12tm]). "Something of the transcendental" ("Du transcendental"), i.e., that which does not properly belong to historical experience but would be its condition of possibility: a set of invariant elements or permanent structures that form a system.' See as well Collins, “An Anthropological Turn?” Collins identifies Gauchet alongside Régis Debray, Emmanuel Todd, and Alain de Benoist as a leading figure of the new paradigm noted in his title. ' $[\mathrm{A}]$ methodological signature of this movement,' he writes, 'was the attempt to synthesize invariant anthropological claims with historicist narratives. The effect was to retain some of structuralism's ahistorical insights - claims about the static components of human society - without abandoning a developmental or historicist framework' (37).

13. The term is Gauchet's. See Gauchet, Disenchantment of the World, 166. Also see Gauchet, La condition historique: 'It so happened I had the gall to define the project as a transcendental anthroposociology, despite the fact that formula is a little ridiculous in its grandiloquence' (13).

14. Lyotard was one of the original members of the Socialisme ou Barbarie group in the 1950s, a cohort of ex-Trotskyists who sought to develop a left critique of Marxism. Its leading figures 
were Cornelius Castoriadis and Claude Lefort, the latter of whom was the political philosopher who would have the most formative influence on Gauchet.

15. Gauchet, "Une Histoire de confection," quoted in Moyn, "Savage and Modern Liberty." Citation on 167.

16. Gauchet, The Disenchantment of the World, 27, 114, 119.

17. Ibid., 161, 189.

18. Three of a projected four volumes have been published. Gauchet, L'Avènement de la démocratie I; Gauchet, L'Avènement de la démocratie II; Gauchet, L'Avènement de la démocratie III. For a cogent analysis of this project, with emphasis on the most recent volume, see Collins's aptly titled review essay "A Metaphysics of Democracy."

19. On Clastres and his importance for a generation of French thinkers, see Moyn, "Of Savagery and Civil Society." The key work of Clastres' truncated output (he died in a car accident in 1977) is the collection Society Against the State [1974]. A brief for a renewal of politica anthropology, grounded in Clastres' ethnological fieldwork in South America, the book resonated deeply with dissident currents in the 1970s and the anti-statism of the antitotaliarian moment more generally. Gauchet takes from Clastres the idea that the locus of modern political forms is effectively anthropological, but he is neither as hostile to the state as such as Clastres was, nor as indulgent in forms of romantic primitivism.

20. Gauchet, The Disenchantment of the World, 107, 13.

21. In an oblique indictment of anarchism, Gauchet targets the 'narrow-minded view of bureaucracy: as a screen between the people and its full sovereignty, a screen to be dispelled. It canno be dispelled because it is through this dispossessive mechanism that the people become sovereign. Nor need we fear the state moloch escaping collective control to enforce its own domination, for it is one of those giants whose benevolence and gentleness increase with its size. Its very capacity to abstract brings it closer to the citizens' (198).

22. Moyn, "Savage and Modern Liberty," 177.

23. Gauchet, The Disenchantment of the World, 199.

24. Ibid., 165, 198.

25. Ibid., 207. For an argument in favor of Lacan's underappreciated importance for Gauchet's thought, see Moyn, “The Assumption by Man of his Original Fracturing," esp. 322-4.

26. Gauchet, The Disenchantment of the World, 101ff, 191, 204.

27. Cf. Toscano, Fanaticism.

28. Marx and Engels, The Communist Manifesto, 38-9.

29. Breckman, The Adventures of the Symbolic, 170. Breckman continues: 'For beneath Gauchet's frequent insistence on the contingency of history is a historical model with a deterministic thrust.'

30. Gauchet, The Disenchantment of the World, 7.

31. Ibid.

32. Ibid., 9 .

33. Tucker, The Marx-Engels Reader, 145.

34. Gauchet, La révolution moderne, 115-25. Cf. Gauchet, La condition historique, 325-65, where the trajectory of the French Revolution is described in terms mainly of the dialectical tension between the symbolic authority of the monarchical form and an ideal of legal impersonality.

35. The key work is Christofferson, French Intellectuals against the Left. Christofferson's work targets the myth that revelations of the Gulag via Solzhenitsyn were instrumental in leading intellectuals away from Communism. Rather, the driving force was a concern for the sclerotic party politics of the French Communist Party and the power it might gain should the Common Program it forged with the Socialists meet with electoral success. The motive for the delegitimation of Marxism on a world scale was decidedly local. For a more wide-ranging assessment of the period, see Bourg, From Revolution to Ethics. For a typically acerbic overview of these shifts in French intellectual life and their relationship to French politics, see Anderson, The New Old World, 137-213. Gauchet speaks of ideologies having been "wiped out" in Disenchantment, 193.

36. Among Lefort's many works, see, in English, Democracy and Political Theory. 
37. Furet, Interpreting the French Revolution. Furet's most imposing work of scholarship is the monumental Dictionnaire critique de la Révolution Française, translated as A Critical Dictionary of the French Revolution.

38. Ibid., 17.

39. For a recent work reflective of (and on) these shifts, see Maza, The Myth of the French Bourgeoisie.

40. A key work inspired by Furet was Hunt, Politics, Culture, and Class in the French Revolution. Cf. Hunt, The New Cultural History.

41. Furet, Interpreting the French Revolution, 58. See Marx and Engels, The Holy Family, or Overshadowed by 'The German Ideology' among Marx's early writings, this volume contains much of Marx's most incisive engagement with the Young Hegelians, as well as key statements of his own views on secularization. See in particular his remarks on Scotist univocity: 'Materialism is the son of Great Britain by birth. Even Britain's scholastic Duns Scotus wondered: "Can matter think?" In order to bring about that miracle he had recourse to God's omnipotence, i.e., he forced theology itself to preach materialism. In addition he was a nominalist. Nominalism is a main component of English materialism and is in general the first expression of materialism' (172, emphasis in original). It probably goes without saying that the nominalist elements of Marx's own conception of materialism have been underappreciated.

42. Furet, Interpreting the French Revolution, 130.

43. See de Tocqueville, The Old Regime and the French Revolution.

44. See Constant, De la liberté chez les modernes. See Marcel Gauchet's introduction, translated into English as 'Liberalism's Lucid Illusion,' trans. Arthur Goldhammer, in The Cambridge Companion to Constant, ed. Helena Rosenblatt (Cambridge: Cambridge University Press, 2009), 23-46.

45. Rosanvallon, Le Moment Guizot.

46. Manent, Tocqueville et la nature de la démocratie. Cf. Manent, An Intellectual History of Liberalism [1985].

47. Constant (1767-1830) was appointed Conseil d'Etat during the July Monarchy and Guizot (1787-1874) became Prime Minister under Louis Phillippe. Tocqueville (1805-1859) long supported the Bourbons, even as he advocated liberal reforms and republican measures within the monarchical setting. Louis-Napoleon Bonaparte's 1848 coup made him despondent over the state of French politics altogether.

48. See Moyn, "Savage and Modern Liberty," 172-5.

49. But even de Maistre, it seems, is not above an attempt at recuperation. See Armenteros, The French Idea of History. Lest we think otherwise, however, Armenteros makes clear that, in her view, Maistre's value is still tied to the putatively salutary qualities of throne and altar: '[T]hrough its monarchical, machine-like rationality, Maistre's pope-church excludes the violence born of the individual will. But perhaps the deepest intricacy is that [...] this church whose government excludes voluntary association is itself the most effective generator of rational association in international politics' (127).

50. Gauchet, The Disenchantment of the World, 192.

51. Breckman, Adventures of the Symbolic, 174

52. This text comes from the series blurb to Lilla, New French Thought, a volume that contains selections from the various authors included in the series.

53. Ibid. This is plainly disingenuous in the case of Gauchet's Disenchantment of the World, a text which accentuates the extent to which, for example, Deleuze's Difference and Repetition and Badiou's Being and Event, are exemplars of theoretical clarity, regardless of one's assessment of the ideas presented.

54. See the works of Moyn and Breckman already cited. Cf. Behrent, "Religion, Republicanism, and Depoliticization." Behrent's writing on Gauchet forms part of a broader and ongoing inquiry into recent French liberalism. See also, Behrent, "Liberalism without Humanism."

55. Moyn, The Last Utopia. In 1980, Gauchet published an article titled "Les droits de l'homme ne sont pas une politique" ("Human Rights are not a Politics") which insisted that mere 
opposition to totalitarianism was insufficient as a political program. Twenty years later, Gauchet published a sequel titled "Quand les droits de l'homme deviennt une politiques" ("When Human Rights Become a Politics"), which laments the ongoing loss of futurity tied to this purely negative conception of politics.

56. Collins, “An Anthropological Turn?” 60.

\section{Funding}

Research for this article was supported by the Australian Research Council [DE140101770].

\section{Notes on contributor}

Dr Knox Peden is an ARC DECRA Research Fellow in the School of Philosophy, Research School of Social Sciences, at the Australian National University. He is the author of Spinoza Contra Phenomenology: French Rationalism from Cavailles to Deleuze (Stanford, 2014) and the co-editor, with Peter Hallward, of a two-volume work devoted to the Cahiers pour l'Analyse (Verso, 2012).

\section{Bibliography}

Anderson, Perry. The New Old World. London: Verso, 2009.

Anderson, Perry. The Origins of Postmodernity. London: Verso, 1998.

Armenteros, Carolina. The French Idea of History: Joseph de Maistre and His Heirs, 1795-1854. Ithaca, NY: Cornell University Press, 2011.

Behrent, Michael C. "Liberalism Without Humanism: Michel Foucault and the Free-Market Creed, 1976-1979.” Modern Intellectual History 6, no. 3 (2009): 539-568.

Behrent, Michael C. "Religion, Republicanism, and Depoliticization: Two Intellectual Itineraries Régis Debray and Marcel Gauchet." In After the Deluge: New Perspectives on the Intellectual and Cultural History of Postwar France., edited by Julian Bourg, 325-349. Lanham, MD: Lexington Books, 2004

Bourg, Julian, ed. After the Deluge: New Perspectives on the Intellectual and Cultural History of Postwar France. Lanham, MD: Lexington Books, 2004.

Bourg, Julian. From Revolution to Ethics: May '68 and Contemporary French Thought. Montreal: McGill-Queen's University Press, 2007.

Breckman, Warren. The Adventures of the Symbolic: Post-Marxism and Radical Democracy. New York: Columbia University Press, 2013.

Cantin, Serge. "Aux sources du Désenchantment du monde de Marcel Gauchet. Éléments pour une généologie.” Studies in Religion/Sciences Religieuses, 34, nos. 3-4 (2004): 495-513.

Christofferson, Michael Scott. French Intellectuals against the Left: The Antitotalitarian Moment of the 1970s. New York: Berghahn, 2004.

Clastres, Pierre. Society against the State. Translated by Robert Hurley in collaboration with Abe Stein. New York: Urizen Books, 1977.

Collins, Jacob. "An Anthropological Turn? The Unseen Paradigm in Modern French Thought." New Left Review, 78 (2012): 31-60.

Collins, Jacob. “A Metaphysics of Democracy.” New Left Review, 74 (2012): 145-154.

Constant, Benjamin. De la liberté chez les modernes: Ecrits politiques. Edited by Marcel Gauchet. Paris: Livre de Poche, 1980.

Furet, François. Interpreting the French Revolution. Translated by Elborg Forster. Cambridge: Cambridge University Press, 1981.

Furet, Francois, and Mona Ozouf, eds. A Critical Dictionary of the French Revolution. Cambridge, MA: Harvard University Press, 1989.

Gauchet, Marcel. L’Avènement de la démocratie I: La révolution moderne. Paris: Gallimard, 2007. 
Gauchet, Marcel. L'Avènement de la démocratie II: La crise du libéralisme: 1880-1914. Paris: Gallimard, 2007.

Gauchet, Marcel. L'Avènement de la démocratie III: À l'épreuve des totalitarismes: 1914-1974. Paris: Gallimard, 2010.

Gauchet, Marcel. La condition historique. Paris: Gallimard, 2005.

Gauchet, Marcel. The Disenchantment of the World: A Political History of Religion. Translated by Oscar Burge. Foreword by Charles Taylor. Princeton, NJ: Princeton University Press, 1997.

Hunt, Lynn, ed. The New Cultural History. Berkeley: University of California Press, 1989.

Hunt, Lynn. Politics, Culture, and Class in the French Revolution. Berkeley: University of California Press, 1984.

Lefort, Claude. Democracy and Political Theory. Translated by David Macey. London: Wiley, 1991.

Lilla, Mark, ed. New French Thought: Political Philosophy. Princeton, NJ: Princeton University Press, 1994.

Lyotard, Jean-François. The Differend: Phrases in Dispute. Translated by Georges Van Den Abbeele. Minneapolis: University of Minnesota Press, 1988.

Lyotard, Jean-François. The Postmodern Condition: A Report on Knowledge. Translated by Geoff Bennington and Brian Massumi. Foreword by Fredric Jameson. Minneapolis: University of Minnesota Press, 1984.

Manent, Pierre. An Intellectual History of Liberalism. Translated by Rebecca Balinksi. Princeton, NJ: Princeton University Press, 1995.

Manent, Pierre. Tocqueville et la nature de la démocratie. Paris: Julliard, 1982.

Marx, Karl, and Friedrich Engels. The Holy Family, or: Critique of Critical Critique. Translated by R. Dixon. Moscow: Foreign Languages Publishing, 1956.

Maza, Sarah. The Myth of the French Bourgeoisie: An Essay on the Social Imaginary, 1750-1850. Cambridge, MA: Harvard University Press, 2003.

Moyn, Samuel. "The Assumption by Man of His Original Fracturing: Marcel Gauchet, Gladys Swain, and the History of the Self." Modern Intellectual History 6, no. 2 (2009): 315-341.

Moyn, Samuel. The Last Utopia: Human Rights in History. Cambridge, MA: Harvard University Press, 2010.

Moyn, Samuel. "Of Savagery and Civil Society: Pierre Clastres and the Transformation of French Political Thought." Modern Intellectual History 1, no. 1 (1999): 55-80.

Moyn, Samuel. "Savage and Modern Liberty: Marcel Gauchet and the Origins of New French Thought." European Journal of Political Theory 4, no. 2 (2005): 164-187.

Rosanvallon, Pierre. Le Moment Guizot. Paris: Gallimard, 1985.

Rosenblatt, Helena, ed. The Cambridge Companion to Constant. Cambridge: Cambridge University Press, 2009.

Scott, Joan. The Politics of the Veil. Princeton, NJ: Princeton University Press, 2007.

de Tocqueville, Alexis. The Old Regime and the French Revolution. Translated by Stuart Gilbert. New York: Random House, 1955.

Toscano, Alberto. Fanaticism: The Uses of an Idea. London: Verso, 2010.

Tucker, Robert C., ed. The Marx-Engels Reader. New York: Norton, 1978

Weber, Max. "Science as a Vocation." In From Max Weber: Essays in Sociology, edited and translated by H. H. Gerth and C. Wright Mills, 129-156. New York: Oxford University Press, 1946. 